\title{
Shirkah
}

Journal of Economics and Business

Vol. 4, No. 2, May-August 2019

ISSN: 2503-4235 (p); 2503-4243 (e)

\section{Editor in Chief}

Fitri Wulandari

\section{Managing Editor}

Jasanta Peranginangin

\section{Editorial Boards}

AAbdul Azim Islahi,

Islamic Economics Institute, King Abdulaziz University, Saudi Arabia

Abu Umar Faruq Ahmad,

UBD School of Business and Economics Universiti, Brunei Darussalam

Cedomir Nestorovic,

ESSEC Business School Asia Pacific, Singapore

Johan Fischer,

Department of Social Sciences and Business Roskilde Universitetscenter, Denmark Muhamed Zulkhibri,

Islamic Research and Training Institute, Islamic Development Bank, Saudi Arabia M. Kabir Hassan,

Department of Economics and Finance, University of New Orleans, United States Musa Asy'arie,

Faculty of Islamic Economics and Business, IAIN Surakarta, Indonesia

Nunung Nurul Hidayah,

Aston Business School, Aston University, Birmingham, United Kingdom

Saim Kayadibi,

Department of Economics, Kulliyyah of Economics and Management Science,

International Islamic University Malaysia, Malaysia

Shaikh M Ghazanfar,

Departement of Economics, University of Idaho, Russian Federation 
Sigit S. Wibowo,

Department of Management, Faculty of Economics and Business, Universitas Indonesia, Indonesia

Vihang R. Errunza,

Desmarais Global Finance Research Centre, Desautels Faculty and Management, McGill University, Canada

\section{Assistant to Editor}

M. Endy Saputro

M. Zainal Anwar

Shirkah Journal of Economics and Business is a peer-reviewed journal published three times a year (January-April, May-August and September-December) by Faculty of Islamic Economics and Business, Institut Agama Islam Negeri (IAIN) Surakarta Central Java, Indonesia. The main objective of Shirkah is to offer an academic space of exchange ideas and initiate the increase number of qualified article produced by postgraduate students, practitioners and academicians.

\section{Editorial Office}

Ruang Jurnal Shirkah

Lantai Dasar, Sayap Barat, Fakultas Ekonomi dan Bisnis Islam, IAIN Surakarta

Jln. Pandawa No. 1, Kartasura, Sukoharjo, Jawa Tengah Kode Pos. 57168

Phone (+62271) 781516 Fax: (+62271)782336

E-mail: shirkahjournal@iainsurakarta.ac.id; shirkahiainsurakarta@gmail.com Website: http://shirkah.or.id/ 


\section{Shirkah}

Journal of Economics and Business

Vol. 4, No. 2, May-August 2019

ISSN: 2503-4235 (p); 2503-4243 (e)

\section{Table of Contents}

\section{Articles}

Abd Hannan

Santripreneurship and Local Wisdom Economic Creative of Pesantren Miftahul Ulum

Muh. Salahuddin

Nurhilaliati

Zaenal Arifin

Entrepreneurship and Economics of Pesantrens in Lombok Island

Abdul Jalil

Alumni Networks and Economic Reinforcement in Pesantren

Ummussabri

Jehan Maya Zayanie

Ahsana Fitria

Rosidatul Kamariah

Bank Wakaf Mikro and Creative Economics in Pesantren Buntet

Farihatul Qamariyah

Muslim Business Women in Indonesia

Fachrurazi

Dwi Srya Atmaja

Zaenuddin Hudi Prasojo

Muslim Businessmen and Chinese Economics in Singkawang 


\title{
Muslim Business Women in Indonesia
}

\author{
Farihatul Qamariyah \\ Owner of EtniQo Indonesia \& Co-Founder of Buzz Creative Management \\ farihatulqamariyah@gmail.com
}

\begin{abstract}
This study examines the intersection between religion and economic performance through investigating religious ethics and tradition among devout businesswomen. This study also focuses on the issue of spiritual business enterprise. I observed seven Muslim business women as subjects who negotiate a religious and cultural perception of their gendered role in society. During their entrepreneurial journey, Muslim business women transform their conventional company into spiritual - based operations for religious and ethical reason. I undertook nine weeks of fieldwork in urban areas of Jakarta, Purworejo and Yogyakarta. I also conduct life story interview sessions and participatory observation with the seven Muslim business women's project of business including director, manager, employee, and so - called spiritual division. Significantly, the products that they sell reflect spiritual and moral underpinnings. Moreover, the spiritual design of company plays a role in employee screening, training, and benefit, which all incorporate aspects of Islamic practice. This research demonstrates the strong role of religion namely Islam, as evidenced in the Muslim business women's narratives, in functioning as a support system that can greatly enhance the economic and life prosperity.
\end{abstract}

Keywords: Muslim Business Women, religious ethics, spiritual economics, Indonesia

\section{Introduction}

This company's presence is like a noble duty from Allah to create a product of cloth which can cover people aurat, especially for Muslim. Our duty is not merely making product but essentially generating benefits in it. On account of this mission, suggesting all members to always keep reciting dzikir in every single part of the work is a kind of daily advice, since remembering to God and praying must be the soul of the products that we made (interview with Mrs. Iffah M. Dewi, March $3^{\text {rd }}, 2016$ ). 
This proclamation was delivered at the end part of a daily religious ritual by the owner of Sogan Batik Company before the official working hours began. It was arranged in the specific room gathering some employees, the men with proper dressing traditional batik uniform, some of them wearing kopyah (skull cap) and the women with covered praying veil and hijab. This agenda starts around 7.30 am every day during one and half hour practicing some religious activities as the daily tradition. For instances, commencing with reading the Holy Quran verses and the translation alternately by each of member in turn, followed by reciting various Islamic prayers and sholawat, and subsequently praying dhuha together then having a short session religious contemplation are the main daily spiritual practices programmed by the company management. These unusual scenery company activities, in a slight analysis, capture a sense of cultivating spirituality into the individuality and body of company.

The above quote depicts out a short narrative of the meeting point between religion and economic activity through systematic management, principle and tradition. By conducting a fieldwork to seven Muslim business women, my interest is further extended to observe the companies owned by these women that apply a spiritual based operation. I suggest a concept of "spiritual company" that is defined as a new kind of enterprise designation compared with or counter with the conventional system which utilizes a religious prosperity to reach a level of well - developed and success business. This framework refers to "spiritual economy" conceptualized by Daromir Rudnyckyj (2009) and utilizes an idea of "spiritual labor" (McGuire: 2010) in which the business enterprise institution should invite company members for being involved, engaged and experienced the spiritual atmosphere in a workplace. Prominently, this paper attaches an observation to the existence of Muslim business women who transform their secular managerial factory to the spiritual 
company as another form of religious discourse and its connection with economic field.

This paper argues a strong role of religion, in this case of Islam, as a supporting system that could contribute greatly to the economic and life prosperity. Bringing this assumption, I offer another variable of gender, women as subject, as an important framework to come to the stage of dynamic conversation in private and public landscape. In doing so, women affiliation represents an idea of "double" or "multiple" profession in terms of household or family duty as mother or wife and career women as an entrepreneur. By having Indonesian women as subject, Islam as religion, and business as an economic activity, this paper questions on how Muslim business women use religion, Islam, to construct their private and public life and how they implement the religious ethics in their business practice. To elaborate these ideas utilizing some frameworks, firstly I raise up the foregoing reviews on the intersection between religion and business by referring to the initial theory of Max Weber on the Protestant Ethics and the Spirit of Capitalism and the additional framework concerning Islam within Islamic context. Next, I examine the position of women in Indonesia through the gender scholar perspective and put a context of spiritual enterprise in conceptualizing Islam and its market. The following aspect is to display the seven business Muslim women narratives in a short biography and their business story. Subsequently, I analyze the construction of religion in the space of economic practice and finally conclude the discussion by suggesting the utility of religion in business exploration and operation as a form of worship and public piety.

\section{Religion and Business}

Framing religion and economic activity in the landscape of capitalism draws upon Marx Weber's work on Calvinist of Protestantism. 
Weber developed an influential idea of entrepreneurship project driven by the essential ethic of religion called the Protestant Work Ethic (1930). Weber argues that the values of Protestant religious ethics could promote the development of capitalism including the circle of business practice. The Protestant ethic sets out three important characteristics in economic performance: industriousness, asceticism, and wealth (Weber, 1982: p.45). Another important aspect regarding Weber's idea of engaging religion with economic activity underlines a concept of "God Calling" (1982). This idea inclines a basic value to reach a business progression. In illustration, a man who has a great wealth coming from the result of economic practice could be indicated as a person who is elected by God in the sense of spiritual relationship. Noticeably, the more prosper man is in economic sector the more he is characterized as an elected person in God level. This illustration demonstrates a function of religion that plays an important role in influencing the economic development.

With regards to a comparative discourse on religion, Weberian thesis collocates such differentiation among the world religions in qualifying the spirit of capitalism related to business practice. In Weber's assumption, besides Buddhism that has no a strong connection with economic growth (Harvey, p.206), Islam is not also involved in the progress of capitalism due to some historical reasons. Briefly, Islam could not produce a success of capitalism due to the incompatible culture of Islam and the spirit of capitalism. The cultural reasons are linked to warrior ethics, worldly Sufism and patrimonialism. It is in accordance with Bryan S. Turner's interpretation in testifying a Weber's argument. "Islamic institutions were incompatible with capitalism because they had been dominated by a long history of patrimonialism.” (p.231), this proclamation underlines a significant framework to take Islam as a religious institution and its intersection with economic performance namely business 
practice from the scope of Indonesian Muslim women context to testify the qualification.

As an early theory of religion and capitalism, Weber's view point produces some debates on scholarly document as the following responses. The dynamic discussion between Islam and capitalism is still going henceforth the accelerating cases either identifying Islam through the lens of historical past or the recent observation. In fact, Weber's thesis does not account for the generalization of space especially religious institution. A peculiar source declares that Islam has an ultimate lineage of economic motivation based on the prophetic principle. Historically speaking, Prophet Muhammad, a man who got a revelation of Islam and whose profession was a merchant illustrate narrative on Islam that becomes the only major world religion revealed through a businessman (Ahmad, 2004). It confirms the contextual case of Indonesian tradition according to the narratives of "Islam as religion of traders and exalted entrepreneurs" and it is a kind religion of traders, born in a trading city, and spread over the world by the traders, which legitimately advocates the act of entrepreneurship and given a privilege to pay a benefaction from the livelihood (Hoersterey, p.103 104). This annotation can be a pragmatic clue for Islam to demonstrate the idea of economic activity. These evidences significantly indicate the identity of Islam which historically cannot be separated from a practice of economy.

\section{Women Subjectivities}

Exchanging view on women in several discourses is always appealing to look into the dynamic conversation from year to years and place to places. This part is to explore the women role as a subject for economic activity as well as affiliation. There must be an idea of gender framework when we come to a landscape of women through the eyes of feminism movement especially the issue of private and public. The dichotomy of private and public has an implication of patriarchal system, where private is associated 
with women in domestic aspect whilst public is attributed to man in domination. This assumption tends to explore the demarcation of women in public sphere. Therefore, gender role seems to have a specific frame to observe any historical background of social, economic, and political issue in order to get sense of the identity and significance. Importantly, this idea will subsequently contribute to the understanding of women position and their autonomy in economic participation particularly in the local context of Indonesia.

The portrait of women in $21^{\text {st }}$ century gives an idea of promising space for exposing identity and equality of profession. It takes a landmark of globalization and modernity where women have a similar opportunity to gain the public recognition and acceptance. For instance, women's participation actively in education, politic, and economic development call forth various responses from their proposition of patriarchal social system. In line with this context, women in terms of economic participation has something strongly to deal with educational background. When gender meets education, women fits to their status in social expansion. Taking a supporting worldview from Hull (1982) in Nancy Smith's analysis on the context "Women in Java's Rural Middle Class: Progress or Regress?" can qualify this assumption.

"Models of economic modernization widely assume that educational expansion is always beneficial to the status of women. Women's participation in higher education is seen as conducive to smaller family size, participation in family planning, and most generally, a more egalitarian position for women in the family and public life. Education is also linked, Hull observed, to higher rates of female employment, membership in civic organizations, and the expansion of extra familial social participation (Hull, 1982: p.78-79)." 
Here, the Javanese women as the exemplary illustration has been dealt with some prominent jobs in public life such as possessing a farm land, operating a small business, and managing a family budget (Smith, 2007: p.393). Indonesian women have dynamic roles in terms of private for household matter and public for career supporting the economic domain of husband's and those things contribute to the development of prosperity (Sullivan, p.136). These narrations show a globalized condition and represents an empowered woman in public life due to her educational background and experience. In the other word, education could empower women to the higher social recognition and association. What can be highlighted from this context is on the women play on economic activity. That is, the demarcation of women position in the economic practice and operation has no longer impossible. In such argument, the boundary of private and public is properly associated with the context of role and necessity rather than the linkage of man and women division.

Talking about women role in the economic affiliation, it obviously reminds a significant discourse on women agency through subjectivity and performativity. Both key terms have been used comprehensively by Saba Mahmood (2005) to explain about the case of mosque movement participated by Egyptian women to deal with their social dynamic situation and public relation. She illustrates the narrative on Egyptian women who often meet such pressure and problem as a working woman and prevent them to optimize the realization of religious tradition as a pious member. The point from this expression is emphasized at the notion of how these Moslem women struggle and negotiate with the more complicated situation using their agency and subjectivity to demonstrate their sense of piety in religious landscape. Mahmood's work is beneficially qualified to this context of discussion in terms of women subjectivity specifically in relation with economic activity. 
Subjectivity can be conceptualized through a presence of agency. In Mahmood's explanation, understanding the subjectivity of women in their social circumstance as well as religious tradition could be evaluated from women's own motivation and reason not from the others locus of concern. She emphasizes at the discourse on understanding women through their nature and scope of agency particularly on how these Moslem women live with the Islamic virtues and traditions to inhabit the structure of patriarchal norms and what kind of resources and religious modes that differentiate them from others (p.168). Contextually speaking, a way to understand the women's role and agency in their social, religious and cultural context can be potentially available if it comes to see them not from partial evaluation but rather invite them into the agent of conversation. Therefore, to have a definition on public and private for women is something significant to see through their agency and subjectivity as what Mahmood's suggestion at her text. Whether it is public or private, domestic or business, to evaluate women subjectivity in economic activity from the lens of gender must figure out the framework of essential and pragmatic context of evidence from the actor's narrative and experience.

\section{Spiritual Economy for Spiritual Company}

To come up with this point, witnessing the emergence of several factories which transform their company model from a secular or conventional way in Indonesia becoming spiritual or religious create the impression of progressive religious resurgence in a public sphere particularly in a workplace. As a pre - assumption, a landmark of globalization testifies the notion of religious triumph in the context of economic activity. Some concerns on public piety, religious ethics, devotion, service, and business virtues in workplace are the conversation around it. This sub division 
captures the present cases in Indonesia which correspond to Daromir Rudnyckyj's work on spiritual economy in the record of market Islam (2010). His work concerns on the movement of a moderate Islamic spiritual reform in Indonesia occupied at the private companies, state owned enterprise and government offices. In a sense, the way of Rudnyckyj describing and analyzing the topic within the framework of theoretical approaches from the side of Islamic background, business, and globalization knowledge assist this research in a comparable worldview.

Defining a spiritual company as another model of enterprise designation which exclusively brings religious substances in its operation utilizes a concept of spiritual economy by Rudnyckyj for the comprehensive understanding. "The convergence of religious ethics and business management knowledge illustrate the formation" is the basic term of spiritual economy (2010: p.132). Religious piety and spiritual values are conceptualized as the significant matters which embodied in economical process. According to Rudnyckyj's classification, there are three interrelated components of spiritual economies: (1) Objectifying spirituality as a site of management and intervention; (2) Reconfiguring work as a form of worship and religious duty; (3) Inculcating ethics of individual accountability that are deemed commensurable with neoliberal norms of transparency, productivity, and rationalization for purposes of profit (2010: p.105). These three elements invokes the company members to be more religious and pious that could determinately influence to their productivity of work.

\section{Seven Women}

In this section, extract the narratives from seven Muslim business women in terms the dynamic biography of life and entrepreneurship journey would be the important framework to deal with the outcome in analytical 
discussion. To begin with my first impression evaluating the respondents' story of life, I highlight a primary issue of individual transformation exactly in spirituality as well as religiosity caused by some certain historical events and awareness. My argument is that the spiritual transformation experienced by these women in the narratives support their initiation to change the concept of business from the common business enterprise design becoming the Islamic - based operation. In other words, the process of undergoing the business has come to the stage where spiritual journey inspires the respondents' business model afterward. I call this situation as "born again Muslim women" who have encountered a self - spiritual transformation through agency and ultimate power in order to gain the meaningful life orientation.

Spiritual transformation is always a matter of self-awareness, the interaction between the self and a power (source, agency) beyond the self. Religious experiences are spiritual experiences when they convey ultimate meaning for a person. For religious people, a superhuman power is the ultimate reality in which human beings can overcome their divided self. God is both the source and ultimate destiny of the self to become one's true self (Hermans, 2013: p.169 - 171)

In reference to this idea, they are Iffah M Dewi (34), Siti Hariani (42), Atika Kurnia Sari (32), Sri Budi Rohani (52), and Restyana Widya Putri (29), the Muslim business women who represent the narrative of spiritual transformation. Based on the result of interview session, most of these women previously did not concern with religious and spiritual activity in their daily life even in the business matter. Even for the personal religious practice, they merely perform as the way it is without such profound concern and devotion. What I record from the clear acquisition is about the sense of non - religious and spiritual attachment either daily life or business practice. In addition, on their career as business women, 
the idea of religion which has nothing to do with business progression is obviously confirmed. That is, the notion of secularization seems to become a basic idea for a tenet of religion in business operation. The purpose of business that covers a pragmatic goal such as a profit oriented does not generate any significance when it comes to religious institution in it. In fact, the narrative speaks for any single evidence. The conflicting area and problematic experience become the potential trigger of their transformation.

My company applies a western working concept for some years of execution, in which the business orientation is all about getting a great profit, high demand, and large market. By the time, there were some unpredicted accidents happened in out of our control. Many problems raised up and everything was often obstructed. We got so many bad lucks. Even though this company has achieved many successes but happiness is not inside of me (interview with Atika Kurnia Sari, February $1^{\text {st }}$, 2016).

This statement was conveyed by Atika in one of her confessions at the time where a spirituality is out of her concern during the business journey. To give a short review, those critical conditions historically lead her to figure out a peculiar solution and rethink a component that she has not inserted yet in the body of company which is a spirituality. Beside this background, the presence of spiritual teacher or guru who guides her in initiating the action might be the important narrative as well. Alike Hariani, Iffah, Sri and Restyana who have almost the same experience as Atika in encountering their spiritual spot of context such as an emptiness of success, a family trouble, an absence of happiness as well as an apprehensive about future that tend to be the core of reason. Afterward, the dependent sense to religion turns to be a primary concern. By the process, their daily life has changed totally to the Islamic - based tradition in terms of religious practice, communication and life style by fulfilling 
the Islamic order and applying the Islamic teaching in their family culture and business nature.

The division subsequently transmits the other narratives on two respondents, Diajeng Lestari (30) and Nur Arifah (27) who identify themselves with the kind of symbolic representations. Diajeng with her initiation of being nationalist at the same time Islamist and Nur with her status of being hafidzah and the life time of pesantren student are strongly remarkable in their personal branding and character. Aside from the five women in the previous discussion, these Muslim women have a appealing story on their personal life and how they finally initiate their business enterprise through the self - representations. In fact, these two women have affiliated to Islamic tradition and education since their childhood through the family background and religious institution. Hence, it can be evaluated that they do not experience such kind of religious and spiritual transformation. In the other words, these respondents historically have attached to Islamic environment since the beginning of their journey of entrepreneurship and daily life.

Furthermore, I elaborate two important narratives displaying these seven Muslim business women narratives on religious affiliation that are "born again Muslim women" and the "deep - rooted Islamic tradition" according to the evidences. The classification influences to the standing point where their business designation is centralized either secular or religious reference. Here, the narrative of Diajeng with her company HijUp.com and Nur with Neana brand business perpetuate in Islamic nuance since the earlier establishment which is conversely different from the five other respondents.

In addition, between private and public, these two different spaces are always stated at the very critical distinction, however, the demarcation is not often clear. Through the understanding, the seven Muslim business 
women have set up their private and public matter in such kind of negotiation. I frame this context into religious, social and cultural reference. Living in the area of Islamic family and Indonesian environment does not prevent them to exist in both private and public sphere actively. The term of self and women - empowerment is highly respected in this context. To them, by being women entrepreneur as a public career contextually support their agency to deal with private aspect as an autonomy especially in terms of household matter. For instance, the management of quality time for family tends to be facilitated through a fair negotiation.

Becoming an entrepreneur precisely give me so much time for family. We can manage and enjoy every quality time we want. Even though I am busy, my children are still able to see me at home. If I should go for two or three days for business agenda, what I need is only telling them in a discussion. It is important (interview with Siti Hariani, February $22^{\text {nd }} 2016$ ).

The choice of being entrepreneur as a career might be one of the reasons to deliberately control their private organization in family circumstance. In the opinion of responsibilities to fulfill the duty of being wife for their husband, mother for their children and business person for their company, they carry them out effectively. As a result, negotiation seems to be an important key behavior for the Muslim business women's subjectivity to deal with their area of private and public as a fair communication and solution.

\section{Islamic Ethics and Business Activity}

Religion could shape human's tradition and culture (Bauman et al, 2011: p.14). This statement might become a starting point to begin with the discourse of understanding the construction of religion in the Moslem business women's story of economic activity. Pragmatically, religion 
obtains a significant role and position in most people's coexistence to its instrumental provisions. Based on the findings, I evaluate some explorations and centrality of religion in the Muslim business women's business project which can be justified from some characteristics:

(1) a philosophical meaning of official business names, (2) a company model in terms of principle, management, and tradition within employment and (3) product launch, design and selection. Through this classification, I apply a term of spiritual company and use a concept of spiritual labor suggested by Tammy McGuire to understand how religion is being implemented in the process of working in the business enterprise tradition. The actualization of spiritual company and spiritual labor incorporates Islamic source of teaching and practice as the basic inspiration, guidance and reference.

In analysis, the first characteristic in the construction of religion is begun with naming the official business which represents an Islamic nuance within the body of company. In a philosophical brand of meaning, HijUp owned by Diajeng Lestari is inspired by the word of Hijab. It demonstrates a symbolic facet of Moslem women attribute then it is followed by "Up" as like in the phrases of dress up and make up. The interpretation behind creating this brand is about the meaning of Hijab in a contextual way, in which, Moslem women do not limit themselves to produce their masterpiece of Islamic design on fashion, they could be acknowledged widely in the public area by such kind of acceptance and appreciation. The most importantly, both the designers and customers enable to perform their fashion look of style beautifully following the modern trend but still apply the guidance of shar'i. Diajeng also adds a substantial intention regarding her business project in terms of Islamic mission through the fashion industry to empower Muslim women with their skill and creativity. 
The Muslim fashion industry is not a regular business. We contribute to spread the positive image of Islamic world. It is an evidence that Allah loves beauty. The impact of this project, we shared Islamic values, not just latent function but also manifest content. We empower each other and seek Allah's mercy (interview with Diajeng Lestari, March 31 2016 ).

Further explanation on the company principle can be seen from Sogan Batik Company owned by Iffah M Dewi. She conceptualizes her business project with a basic ethic of Batik Berdzikir. According to her narration, the point of this ethic is about the real ownership of the company, meaning Allah in reference and the members are just merely the operator. Since her product is a Muslim fashion clothing made in batik pattern, all the inspirations regarding the philosophy of cloth meaning and design are inspired by Islamic history and figure. In the other words, she utilizes a variety of Islamic terms and histories to design the model and to name the cloth collection. Inserting Batik Berdzikir as the important philosophy of this company expects something beyond the execution namely all the process productions starting from designing cloth, sewing, packaging until the shipment to customer, all members must invite Allah with Dzikir in terms of remembrance and personal requirement. Importantly, she generates this principle into the company ritual and tradition among the employees. This context confirms to what Daromir Rudnykyj has conceptualized on spiritual economy (2010) in reverse the notion of "Objectifying spirituality as a site of management and intervention".

Working is worshipping. This idea implies a centrality of religion in the form of spiritual company tradition. Hariani with her company, Waroeng Steak and Shake, has deeply rooted at this idea of working as a manifestation to worship God, Allah SWT. In another word, the orientation of undergoing business is not only about a financial target as 
such salary or profit but it attaches an intention of akhirat or hereafter. To work is essentially also included in the way to fulfill the religious duty. The tradition of five compulsory prayers in jamaah and to memorize certain verses of $\mathrm{Al}$ Quran are the examples of implementing Islamic practice in the ritual of company. This documents significantly confirms the second component of spiritual economy by Rudnykyj that is "Reconfiguring work as a form of worship and religious duty" (2010). The narrative also shows a concept of where those who can fulfill the company's goal in religious ritual will be awarded to go pilgrimage to Mecca and Medina. This kind of promising reward encourages the members of company to be actively involved in cultivating the religious ethics and tradition into their daily working activity. Evidently, these kinds of traditions interpret the essential meaning of spiritual labor which manifested in members' enrichment of spiritual worldview and practice. Moreover, Waroeng Group declares an outstanding principle regarding a device to monitor the members' process of working beyond the technological tool which is Allah as the ultimate CCTV. This aspect points out a facet of God's involvement in the working process that is obviously directs to the religion as the center of direction.

Alike Neana Company owned by Nur Arifah, she conceptualizes its tradition as like in Pesantren especially the daily business ritual. For instance, before start working, there is one session of Pengajian Kitab Kuning (traditional religious study) for the employees which take some topics on the classical Islamic book concerning women discussion. Then, it is followed by the session of reading Al Quran regularly from each member, reciting sholawat and Islamic prayers together. Interestingly, this company has a certain ritual of religious practice referring to the production process. As an example, when this company will launch a new product started by designing the new model, fabric, and aspect related to the preparation, the owner and members of company practice hajat prayer. Another 
surprising ritual as the simple instance is when the product pictures will be uploaded to website or posted to social media account, the members are instructed to get use to pray. In this evaluation, the company creates a spiritual tradition even for trifling or small matter. Briefly, every single commencement of work, praying is an obligatory action. To precede Allah before anything is its strong ethic of principle. The implementation of spiritual company is inherently attached to every corner of the business operation such as the qualification, production, selection, etc. According to Nur's expression, everything goes well because of Allah in hands and God is the medium among the members, the company, and the market. In another word, it can be analogized as if Allah will, everything will be real.

The reason of people purchasing my product is because of Allah. He moves people hearth to buy and make my clothing sold out significantly. Hence, I and the members of company always try to approach the people's hearth owner, Allah, before touching the customer spot. I believe, whatever the product is, how expensive the price is, people will buy if Allah will. When we run for the door of Allah, He will open greatly to us. Therefore, I depend anything to Allah even for the small things (interview with Nur Arifah, February $18^{\text {th }}$ 2016).

Framing business from Islamic perspective, a product becomes one of the important things in concern, moreover when it comes to the aspect of food as a culinary business sector. As an ethical reason, halal (lawful) and toyyib (wellness) are the standardization to fit to Islamic values. The construction of religion in this context can be analyzed from the narrative of Restyana Widya Putri who owns a cake bakery business. A product substance selection is the main crucial thing she dealt with particularly in terms of composition and the tool of production. By applying the spiritual company model, she assures convincingly that every single process of her cake production is accordance with Islamic standard and it does not contain something prohibited by Islam. Responding to 
this context, Restyana confidently says, "Kuki Bakery should become the first cake bakery company which applies an Islamic process of business and production. I challenge myself to succeed this mission because of seeing most of the presence cake companies in this country are dominated by the non - Moslem enterprises which obviously have no consideration and care about the ethics of Halal and Toyyib" (interview with Restiana Widya Putri, March $8^{\text {th }}$ 2016).

Referring to another narrative comes from Sri Budi Rohani. She brands her company as the best sharia retail in the world which consists of six principles - based Islam: (1) shar'i, (2) add values, (3) team work and high performance, (4) responsibility, (5) integrity and commitment, and (5) abundance and grateful. In the execution, Mina Store prioritizes the business orientation which embraces a motivation of worship to God. Qualification and selection for the membership association (i.e. Islam in identity and wearing headscarf or veil for women) and product including the cooperation with the suppliers are strictly evaluated. As an example, after applying the spiritual company, this store did not sell a product of cigarette and condom anymore whereas these two kinds of product have a higher margin in profit compared to the other items. This decision is based on the company principle that brings a religious reason.

We change the product of cigarette because there is an issue of pro and contra of its presence. The product of condom as well, we finally know that this product is misused by non - married couple. Even though these products have a great accumulation in profit while we know that Islam prohibits them. We challenge our company to stop selling them and replace by other the other products such as cloth and food. In fact, we got a surprised feedback from this execution gratefully (interview with Sri Budi Rohani, March 9 ${ }^{\text {th }}$ 2016). 
The great transformation leads this company to expand the business scope which becomes Mina Group under twelve branches spreading in Yogyakarta regency. Rohani expresses the highest motivation for the next actualization of business which is about an act of devotion toward religion and it has nothing totally to do with a material matter. Because materiality comes after the sense of spiritual well - being and piety, she confidently convinces the outcome of this belief afterwards.

In elaboration, the Muslim business women's narratives in spiritual transformation construct religion, in this case Islam including the ethics and principle, as a significant bridge to deal with their economic project and execution. The ways they implement these ideas impressively centralize to every single area of business organization: principle, management, product and tradition in the workplace by inviting all members in company without exceptional classification. Briefly, Islam has embedded inherently within the very small piece matter of business operation and practice and it represents two orientations as the principle and execution: they are a profit enrichment and eternal achievement.

\section{Conclusion}

This paper proves a contextually evident of Indonesian Muslim women subjectivity as the frame of reference in establishing the situation where prosperity and development are supposed to be the male dominated profession in terms of livelihood and financial matter. The foregoing arguments on Indonesian context exactly the Javanese women have testified the present narratives that display a strong agency of Muslim women within their private and public matter with the so called "multiple" role in controlling family in household and company in business enterprise. The story of spiritual transformation in most of their life journey depict a representation of spiritual seeker that consequently 
leads them to the individual awareness toward the ultimate concern.

This research additionally reveals the role of religion and women participation in economic business performance through narratives and experiences. By examining the dynamic exploration of Islamic source and tradition in the way how business project is designed, operated and managed, it demonstrates a utility of religion namely Islam as a supporting system to the benefit earning and employment training for the enrichment of whole objectives of enterprise. As a result, the seven Muslim business women significantly transform the ideal mindset of conventional business, in which profit and materialistic orientation as set the top of target, into the religious objective goals namely ultimate situation in eternity as the process of religious construction. In this case, spiritual company and spiritual labor are the manifestation to interpret a working business as another form of worship to God with the different designation and implementation. Meanwhile, performing the religious and Islamic ethics with the collective members in business environment as a company tradition indicate an issue of public piety through cultivating spirituality within the everyday activity as a part of the company order which is in line with Islamic provisions.

\section{Acknowledgement}

This paper was presented at the 11th Singapore Graduate Forum on Southeast Asian Studies on 14th of July 2016 at National University of Singapore and 27th International Research Conference on Business, Economic and Social Science on 1st of August 2016, Istanbul, Turkey. 


\section{References}

Ahmad, Imad-ad-Dean. (2004). Islam, Commerce, and Business Ethics. Minaret of Freedom Institute: Loyola Institute for Ethics and Spirituality in Business

Bauman, Whitney et al. (2011). Grounding Religion: A Field Guide to the Study of Religion and Ecology. London, New York: Routledge.

Harvey, Peter. (2000). Introduction to Buddhist Ethics: Foundations, Values and Issues. United Kingdom: Cambridge University Press.

Hermans, Chris.A.M. (2013). Spiritual Transformation: Concept and Measurement. Journal of Empirical Theology 26 (2013) 165-18.

Hoesterey, James B. (2015). Rebranding Islam: Piety, Prosperity, and a SelfHelp Guru. USA: Stanford University Press.

Hull, Valerie J. (1976). Women in Java's Rural Middle Class: Progress or Regress? Yogyakarta: Population Institute, Gadjah Mada University.

McGuire, Tammy. (2009). From Emotions to Spirituality: "Spiritual Labor" as the Commodification, Codification, and Regulation of Organizational Members' Spirituality. Management Communication Quarterly 2010 24: 74.

Mahmood, Saba. (2005). The Politics of Piety: The Islamic Revival and the Feminist Subject.

Princeton: Princeton University Press.

Rudnyckyj, Daromir. (2009). Spiritual Economies: Islam and Neoliberalism in Contemporary Indonesia. Cultural Anthropology. Vol. 24, Issue 1, pp. 104-14.

Rudnyckyj, Daromir. (2010). Market Islam in Indonesia. The Journal of the Royal Anthropological Institute, Vol. 15, Islam, Politics, Anthropology, pp. S183-S201.

Smith - Hefner, Nancy J. (2007). Javanese Women and the Veil in PostSoeharto Indonesia. 
The Journal of Asian Studies, Volume 66, Issue 02, pp 389 - 420.

Sullivan, Norma. (1994). Masters and Managers: A Study of Gender Relations in Urban Java. Australia: Allen and Unwin.

Turner, Bryan S. (1974). Islam, Capitalism and the Weber Theses. The British Journal of Sociology, Vol. 25, No. 2.

Weber, Max. (1920). The Protestant Ethics and the Spirit of Capitalism. New York: Scribner.

\section{Internet Sources}

Tentang TDA. (2006). Retrieved from www.tangandiatas.com in March 2015.

Jogja Muslimahpreneur Community. (2015, January 12). Retrieved from www.jogjamuslimahpreneur.blogspot.com in June 2015.

\section{Interview}

Interview with Mrs. Iffah M. Dewi, the owner of Sogan Batik and Sagan Resto located in Sleman. Thursday, $3^{\text {rd }}$ March 2016.

Interview with Atika Kurnia Sari the owner of Bajuku Indonesia and Mangrove Group located in Bantul, $1^{\text {st }}$ February 2016.

Interview with Siti Hariani, the owner of Waroeng Steak and Bebek Goreng Hj. Slamet located in Yogyakarta, 22 ${ }^{\text {nd }}$ February, 2016.

Interview with Diajeng Lestari, the owner of HijUp Company located in Jakarta, $31^{\text {st }}$ March 2016.

Interview with Nur Arifah, the owner of Neana Brand Company located in Puroworejo, $18^{\text {th }}$ February 2016.

Interview with Restiana Widya Putri, the owner of Kuki Bakery, $8^{\text {th }}$ March 
20162016.

Interview with Sri Budi Rohani, the owner of Mina Group, Wednesday, $9^{\text {th }}$ March 2016. 
Vol. 4 No. 2, May - August 2019 


\section{Shirkah Author Guidelines}

Shirkah currently offers two routes to submit manuscripts. We highly recommend to submit the articles which are made using OJS (Open Journal System). Feel free register as author soon through visiting http:// shirkah.or.id/index.php/home/user/register. The authors may directly send their manuscripts, along with their resume, to shirkahiainsurakarta@ gmail.com. Please prepare your manuscripts, using following guidelines:

1. Manuscript must be written in English. Submitted articles should not have been published or be under review for publication with another journal.

2. Manuscript's length is about $15-20$ pages, typed in one-half spaced on A4-paper size.

3. Manuscript must include an $150-200$ word abstract and keywords.

4. Manuscript must be arranged as follows: Title, Name of Author, E-mail address, Abstract, Keywords, Introduction (including method if any), Discussion, Conclusion, References.

5. Manuscript's titles not more than ten words.

6. Manuscript must be submitted in Microsoft Word or RTF.

7. Arabic words should be transliterated according to the style of International Journal of Middle Eastern Studies.

8. Manuscript references are preferably derived from the up-to-date references.

9. The author's resume should be submitted separately, consisting of at least full name, institutional address, phone number, areas of studies, and recent publications (if any).

10. Shirkab use APA Style 6th edition (2010) as reference format writing. We suggest the use of a reference manager software such as Mendeley, Zotero, and Endnote at templating the citation style. APA Style to be used is as follows: 


\section{Book with single author}

Swann, G. M. Peter. (2014). The Economics of Innovation an Introduction. Cheltenhum \& Northampton: Edward Elgar.

in-text citation: (Swann, 2014)

\section{Articles in reference books}

Alatas, S. F. (2006). Islam and the Science of Economics in Abu Rabi', I.M. The Blackwell Companion to Contemporary Islamic Thought. USA: Willey-Blackwell (pp. 587-606).

in text citation: (Alatas, 2006)

\section{E-Book}

Hackett, Rosalind (2007). "Religous Dimentions of War and Peace: Introduction.” Dalam Gerrie ter Haar dan Yoshio Tsuruoka (Ed.), Religion and Society: An Agenda for the 21st Century (h. 3-6). Retrieved from http:// brill.nl.

in text citation: (Hackett, 2006)

\section{Master's thesis, from a commercial database}

McNieI, D. S. (2006). Meaning through narrative: A personal narrative discussing growing up with an alcoholic mother (Master's thesis). Available from ProQuest Dissertations and Theses database. (UMI No. 1434728)

in text citation: (Mc Niel, 2006)

\section{Doctoral dissertation, from an institutional database}

Adams, R. J. (1973). Building a foundation for evaluation of instruction in higher education and continuing education (Doctoral dissertation). Retrieved from http://www.ohiolink.edu/etd/

in text citation: (Adams, 1973) 


\section{Doctoral dissertation, from the web}

Bruckman, A. (1997). MOOSE Crossing: Construction, community, and learning in a networked virtual world for kids (Doctoral dissertation, Massachusetts Institute of Technology). Retrieved from http:/www-static. cc.gatech.edu/--asb/thesis/

in text citation: (Bruckman, 1997)

\section{Journal article with No DOI}

Bourkhis, K., and Nabi, M. S. (2013). Islamic and conventional banks' soundness during the 2007-2008 financial crisis. Journal Metrics, 22(2), 68-77.

in-text citation: (Bourkhis \& Nabi, 2013).

\section{Journal article with DOI}

Ichwan, M. (2012). The Local Politics Of Orthodoxy: The Majelis Ulama Indonesia in the Post-New Order Banten. Journal Of Indonesian Islam, 6(1), 166-194. doi:http://dx.doi.org/10.15642/JIIS.2012.6.1.166-194

In text citation : (Ichwan, 2012)

\section{Abstract as citation}

Hasan, N. (2012). Islamist Party, Electoral Politics And Da'wah Mobilization Among Youth : The Prosperous Justice Party (PKS) in Indonesia. Journal of Indonesian Islam, 6(1), 17-47. Abstract from http:// jiis.uinsby.ac.id/index.php/jiis/article/view/97

in text citation : (Hasan, 2012)

\section{Mass media article}

Sahal, Akhmad (2014, March 2). Kiai Sahal dan Realisme Fikih.Tempo Magazine, p. 120.

in text citation : (Sahal, 2014) 


\section{Research report}

Fisher, B. S., Cullen, F. T., \& Turner, M. G. (2000). The Sexual Victimization of College Women. Research Report.

in text citation : (Fisher, Cullen, Turner, 2000)

\section{Monograph}

Routray, Bibhu Prasad (2013), National Security Decision-Making in India (RSIS Monograph No. 27). Singapura: Rajaratnam School of International Studies.

in text citation : (Routray, 2013)

\section{Proceeding article}

Sudibyakto, Hizbaron, D.R., \& Jati, R (Ed.) (2009), Proceeding International Seminar Disaster Theory, Research and Policy. International seminar held by Sekolah Pascasarjana, Universitas Gajahmada, Yogyakarta, 8-9 Desember 2009.

in text citation : (sudibyakto and Jati, 2009)

\section{Paper conference/seminar/symposium}

Janutama, Herman Sinung (2011). "Kraton dan Hubungan Antar Agama." Paper presented in Seminar Kraton dan Panatagama held by Center for the Study of Islam and Social Transformation (CISForm), Yogyakarta, 17 November.

in text citation :(Janutama, 2011)

\section{Online article in web}

Shiva, (2006, February). Bioethics: A Third World Issue. Native-web. Diperoleh dari http://www.nativeweb.org/ pages/legal/shiva.html

in text citation : (Shiva, 2006) 


\section{Online research report}

Kessy, S. S. A., \& Urio, F M. (2006). The contribution of microfinance institutions to poverty reduction in Tanzania (Research Report No. 06.3). Retrieved from Research on Poverty Alleviation website: http://www. repoa.or.tz /documents_storage/Publications/Reports/06.3_Kessy_and_ Urio.pcif

in text citation : (kessy and urion, 2006)

\section{Holy book}

Qur an, $2(25)$

In text citation : (Q. al-Baqarah 2:25).

\section{Encyclopaedia}

Graycar, Adam (1992). Social Welfare Policy. Dalam Mary Hawkesworth dan Maurice Kogan (Ed.), Encyclopedia of Government and Politics (Vol. 1). London: Routledge.

in text citation : (Graycar, 1992)

\section{Interview}

Sultan Hamengkubuwono X (interview, 2011, April 19)

in text citation: (Hamengkubuwono, 2011)

\section{Documentary film}

Steijlen, Fridus (2008). A Day in the Life of Indonesia [documentary film, 58 minutes]. Leiden: KITLV Press.

in text citation : (Steijlen, 2008) 
Vol. 4 No. 2, May - August 2019 